\title{
Postmodernism: An Anti-Foundational Philosophy of Western Intellectual Tradition
}

\author{
Resham Bahadur Bist
}

Assistant Professor, Central Campus of Humanities and Social Science, Mid-Western University, Birendranagar Surkhet, Nepal

\begin{abstract}
This article attempts to interpret the postmodern philosophy as an anti-essential philosophy of the western intellectual world by incorporating the ideas of postmodern thinkers: Jean Francoise Lyotard, Michel Foucault, Jack Derrida, Jean Baudrillard, Ernesto Laclau, and Chantal Mouffe, etc. Postmodernism appears in a wide variety of disciplines in the contemporary world after World War II. It has dismantled the western intellectual tradition's center seeking tendencies and foundational structure exposing the inherent realities of formulated various discourses of them. The traditional discourses of the intellectual world are reshaped and restructured possessing no universalities in the postmodern era. Similarly, an absolute identity, consciousness, or ego, which is deferred, displaced, fragmented, or marginalized within the structure. Therefore, this article accomplishes the task to analyze how the existing grandnarratives and structure-based philosophical phenomena of the western intellectual circle are subverted using the ethos of poststructuralism and deconstruction, which lie under the postmodern umbrella.
\end{abstract}

Keywords-Postmodernism, Structuralism, Deconstruction, Philosophy, Anti-foundational.

\section{INTRODUCTION}

Postmodernism is the concept that appears in a wide variety of disciplines or areas of study, including art, architecture, music, film, literature, sociology, communications, fashion, and technology after the Second World War. Although, it is hard to locate it temporally or historically because it is not clear exactly when postmodernism begins. There is still controversy among the postmodern thinkers about the emergence of it. The concept of postmodernism appears in the western intellectual circle blurring the tendencies of promoting grandnarratives, foundationalism, logocentrism, hierarchical structure, and center seeking practice, which has been in existence since Greek Classical to the modern period. Regarding the emergence of postmodernism in literature Abram (2005) states:

The term postmodernism is often applied to the literature and art after World War II (1939-45), when the effect on western morale of the First World War greatly exacerbated by the experience of Nazi totalitarianism and mass extermination, the threat of destruction by the atomic bomb, the progressive devastation of the natural environment, and the ominous fact of overpopulation (p.176).

The solid ground of western intellectual tradition has dismantled after World War II. The well-established varieties of structure, norms, and values of society, and the natural environment have deconstructed and destroyed after the massive destruction of World War II. The traditional discourses of the intellectual world are reshaped and restructured possessing no overall design or universal plan; resistant to tantalization or universalities. An absolute identity, consciousness, or ego which are deferred, displaced, fragmented, or marginalize within the structure. The way in which linguistic structure or discourse maintains a radical difference from one another. The relationship among the texts has with other texts or discourse whether on a conscious or unconscious level. It blurs the hierarchy between high and low culture. In this regard, Tim Woods (2011) mentions, "postmodernism pits reasons in the pluralfragmented and measurable against the universality of modernism and the longstanding conception of a human self as a subject with a single, unified reason" ( p.9). As critic points out, postmodernism questions the unified reason for

ISSN: $2456-7620$ 
the western intellectual world. It also gives high priority to the consumerism and globalization.

\section{Emergence of Postmodernism}

The first recorded use of the word 'postmodernism' is back in the 1870s by the English painter John Watkins Capman. He suggests that any art going beyond impressionism, the revolutionary new art style of the period, would be definable as 'postmodern painting'. (Dick Higgins, 1978, p.7). Likewise, the author, Rudolf Pannwitz choose the term "Postmodern' by 1917 to describe the new form of militaristic and anti-humanistic culture developing in Europe ravaged by war (Best \& killer: 1991, p 5-6). The prominent historian Arnold Toynbee (1954) claims that the period from 1875 onwards as the 'Postmodern Age of Western History' ( p. 235) which is marked by the cultural decline because of the divesting two world wars. Eventually, 'postmodern' begins to take on the meaning of 'ultra-modern' with the architectural theorist Jeseph Hundnut deploying it in that fashion to describe the new prefabricated buildings being produced in the aftermath of the Second World War. Hudnut claims that postmodernism is unsentimental and looks to science to improve the quality of life (Hudnut; 1949).

It has proved the postmodernism is rooted in the discipline of architecture. Many architectural theorists popularize the postmodernism as a theoretical concept to develop the international style of architecture by replacing modern architecture. Jencks (1991) famously claims that when one of the most representative examples of the style, the award-winning Pruitt-Igoe housing complex in St. Louis, Missouri, was demolished in 1972, modern architecture died (cited in Sim's 2011, The Rutledge Companion of Postmodernism, ix). After declaring, the demolishing of modern architecture is introduced in which old and new style is being freely mixed. Now, this style of architecture is found in many cities in the world.

The postmodernism begins its widespread journey from architecture and extends to other fields: philosophy and cultural theory; concepts of space; visual art, sculpture and material culture; popular culture and music; film, video and television; and the social science, politics, literature, theory, music, lifestyle, religion, etc. Regarding the wide-spreading nature of postmodernism, J.A. Cuddern (1992) opines, "postmodern is a general term used to refer to changes developments and tendencies which have taken place (and are taking place) in literature, art, music, architecture, philosophy, etc since the 1940s or 1950s" (p.733-34).
Philosopher and cultural theorists have reacted against the traditional paradigms of philosophy and culture. Probably the leading figure of the postmodernism to analysis it, is JeanFrancois Lyotard (1924), a French philosopher, whose book The Postmodern Condition: A Report of Knowledge (1979) is taken as the most powerful theoretical expression of postmodernism.

Several critics have opined regarding the issue of postmodernism; its development, tendencies, and application in the different fields; philosophy, sociology, anthropology, arts, literature, culture, painting, sculpture, etc. About the emergence of postmodernism in literature, M.H. Abram (2005) mentions, "many of the works of postmodern literature- by Jorge Luis Borge, Samuel Beckett, Vladimir Nabokov, Thomas Pynchon, Roland Barthes, and many others-so blend literary genres, cultural and stylistic levels, the serious and the playful, that they resist classification according to traditional literary rubrics" (p. 176). As Abram points out, postmodern literature resists to classical literary trends. Likewise, Ross Murfin and Supria M. Ray (1998) claim that "postmodernism, a term reserving to certain radically experimental of works of literature and art produced after world war II" ( p.297). The tendency of postmodernism is an outcome of the present culture of postmodern society. In this regard, Arkandy Plotnistky (2001) opines that "Postmodern (ist) ideologies of knowledge reciprocally shape and are shaped by postmodern cultural practices" ( p. 266). The changing scenario of the society has emerged the new concept. The paradigms of knowledge are also changed which change the contemporary society and its tendencies. Lytord has mentioned the points dealing with the changing nature of knowledge in the postmodern age. He says, "Our working hypothesis is that the status of knowledge is altered as societies enter what is known as the postindustrial age and cultures enter what is known as the postmodern age. This transition has been underway since at least the end of the 1950s which for Europe marks the completion of reconstruction" (1989; P 3).

\section{STATEMENT OF PROBLEM}

Postmodernism is described as a philosophical movement a form of skepticism and anti-foundational about the authority, received wisdom, cultural and political norms, etc. of a western intellectual tradition. It undermines the tendencies of foundational and grand narrative western thought that begins from classical Greek philosophy. 


\section{The Objective of the study}

The main objective of this article is to analyze the postmodern philosophy as an anti-essential philosophy of highlighting its anti-foundational concept against the existing thoughts of the western intellectual world. Besides this, it has focused to know the tendencies of postmodernism.

\section{METHODS}

This article is an outcome of library research that is fully based on written documents; therefore, the secondary sources of data have only used. It interprets the postmodern philosophy borrowing the insights of some postmodern critics such as Jean Francoise Lyotard, Michel Foucault, Jack Derrida, Jean Baudriallard Laaclau and Moufle, etc as they are relevant to the topic of concern. The researcher has also consulted various books, articles, journals, sites that are related to the study.

\section{Postmodernism: Anti-foundational Philosophy}

The postmodernism is a philosophical movement, which has broken down the received authority, wisdom, cultural and political norms of western metaphysics. It has raised the question against the ultimate truth which was created the foundational discourse of western metaphysics asking the questions as "What guarantees the truth of your foundation?" ( Sim; 2011, p.3). It questions the truth in the long-running tradition of western intellectual thoughts which was grounded in the classical Greek philosophy. It frequently serves as an ambiguous overarching term for skeptical interpretations of culture, literature, art, philosophy, economics, architecture, fiction, and literary criticism. It has been suggested that the term "postmodernism" is a mere buzzword that means nothing. It is a theory of itself "antiessentialist and anti-foundationalist" it is fitting that the term cannot have any essential or fundamental meaning.

To consider the postmodernism's skeptical credentials and anti-foundational discourse, it is helpful to know the various discourses, such as deconstruction, that goes under the name of poststructuralism. The poststructuralism rejects the tradition and thoughts of structuralism. It is one of the gestures of skepticism towards the received authority of the western intellectual world and can be treated as part of the postmodern intellectual landscape. Poststructuralism is a cultural movement that has rejected the methods of structuralism and its ideological assumptions. It is both a philosophical and a historical movement as well, therefore; it is postmodern in general. It ISSN: 2456-7620

https://dx.doi.org/10.22161/ijels.53.8 questions the cultural certainties and methodological key built by structuralism. Structuralism is a theory developed by Swiss linguist Ferdinand de Saussure who revolutionizes the study of linguistics after the publication of his book Course in General Linguistic (1916). According to him, language has governed by a system with rules and regulations. Language is made up of signs, and signs consist of two parts: 'a signifier' (sound/gesture) and 'a signified' (concept). Both of them are combined an act of mental understanding to form a sign. There is not a natural relationship between them; they have an arbitrary relationship with each other but the force of convention has ensured them. The relationship between them depends upon the cultural convention. A certain cultural group has created a certain convention to recognize a particular object. Therefore, they do not change in their meaning by anyone's whim. In the words of Saussure, "there is at the very least relative stability to language and the production of meaning, and language is to be viewed as a system of signs which induced a predictable response on the part of the linguistic community" (Cited in Sim's The Routledge Companion of Postmodernism, p. 4). However, the poststructuralist thinkers subvert the Sassurain idea of the structuralism-the system of language.

Deconstruction, a theory of language developed by Jack Derrida, is based on the belief that language is much more slippery and ambiguous than we realize. Without changing a word, a single sentence can have several meanings. Changes in the tone of voice and emphasis (stress) can further reveal the slippery quality of language. Human utterances are rarely as clear and simple as the structuralist's formula:

Sign $=$ Signifier + Signified $($ Word $)$

(Sound, image, gesture, etc) (The concept to which the signifier refers)

(Tyson, 2008:251)

According to deconstruction a 'word' never reaches the point when it refers to a concept, a signified. The signifier evokes chains of signifiers in the mind of the person who hears the utterance. Moreover, each signifier in those chains is itself constituted by another chain of signifiers, and so on. Therefore, Tyson says, "language is non-referential because it refers neither to things in the world nor to our concepts of things but only to the play of signifiers of which language itself consists" (2008, p. 252). That is why it can be said that communication is a complicated and uncertain thing. The structuralist's formula can be rewritten as: 
Sign $=$ Signifier + Signified + Signified. $($ Word $)$

(Tyson, 2008:252)

Every signifier consists of and produces more signifiers in a never-ending "deferral" of meaning: we seek meaning that is solid and stable but we can never really find it because we can never get beyond the play of signifiers that is language. Tyson (2008) writes:

For deconstruction, (1) Language is dynamic, ambiguous, and unstable, continually disseminating possible meanings; (2) existence has no center, no stable meaning, no fixed ground; and (3) human beings are fragmented battlefields for competing ideologies whose only "identities are the ones we invent and choose to believe. ( p. 258)

A French philosopher Jacques Derrida's deconstruction is one of the most powerful expressions of the poststructuralist ethos. $\mathrm{He}$ is leading light of the poststructuralist intellectual movement that has significantly influenced philosophy, in social science and literary criticism in recent years. Derrida's deconstruction is directed against the system-building side of structuralism.

Derrida is concerned to demonstrate the unstable nature of language and indeed of systems in general. In his view, signs are not such predictable entities and there is never perfect conjunction of signifier and signified to guarantee unproblematic communication. There is always occurred slippage of meaning, and word contains echoes and traces of other words with their sound quality. Derrida provides evidence of this slippage in action employing a concept called 'differance', a term derived from the French word 'difference' which has double meaning 'difference' (to differ) and 'deferral' (to defer/postpone) (Derrida, Margin of philosophy; 1972, p.3). One can not find out which of the two words is intended in speech because they are pronounced the same, different only in writing. Derrida reveals the inherent indeterminacy of the meaning of language subverting the structuralistic notion of language system. He also mentions that linguistic meaning is always an unstable phenomenon everywhere that is guided by the word of 'diifferance'. The 'difference' is not a concept for Derrida, it is only the manifestation of language's instability as well as its endless creative capacity to generate new and unexpected meanings. Meaning is, therefore, a fleeting phenomenon that evaporates almost as soon as it occurs in spoken and written language, rather than something fixed that holds over time for a series of different audiences. Derridain deconstruction is against the logocentric system building tendency of the west which is guided by 'difference'. Therefore, the characteristics of deconstruction are related to the postmodern philosophical ethos.

Michel Foucault (1926-1984) is another postmodern thinker who turns against the system building tendencies of structuralist thoughts. For Foucault, truth itself is the product of a relation of power and the systems in which it follows, it changes as systems change. There are certain systems in society. Therefore, he believes in group power rather than individual power. The group power is formed by many individuals in the society. The society possesses some knowledge under the system. By using such knowledge, society creates discourse. People speak of the ideas that they want. Moreover, they produce speech and write books; this is the process of creating discourse. However, this discourse consists of representation, power, and truth. Power is circulated from different forms of representation: written, audiovisual, and oral. Now this very represented power creates certain truths which ultimately become truth to everyone who is under the system. It means power determines the truth, and as soon as the system of society changes the truth also changes. Foucault's discourse is related to the production of any information that provides knowledge. This knowledge helps create the truth which is neither true nor false. Foucault has exposed how the marginalized groups of people are excluded from political power by setting strict norms of behavior in Western European society. He has written a series of case studies describing how these norms were implemented in seventeenth and eighteenth-century Western Europe. The regimented institutions like insane asylums, prisons, hospitals came in being in order to deal with the 'different' (Foucault;1961). For him, these institutions are an expression of political power and impose the will on others. This idea of Foucault is against the authoritarian tendency of creating the so-called truth in society and associates with postmodern culture.

Jean-Francois Lytoard (1924-1998) is one of the most influential thinkers of postmodern philosophy whose writing consists of the thread of anti-authoritarianism tendency that can be recognized as postmodern. He was described Marxist in his early career. Later on, he distanced self-consciously himself from his Marxist past. His most influential work The Postmodern Condition: A Report of 
knowledge (1979) has appeared a critique of 'grand narrative'. He begins his book by pointing out how the field of knowledge has changed in the years after World War Second. He emphasizes on the anti-foundational and antiholistic aspects of French theory as well as its hostility to eternal metaphysical truths or realities and grand narratives. In this regard, he says in The Postmodern Condition, "simplifying to the extreme, I define postmodern as incredulity towards meta-narratives. This incredulity is undoubtedly a product of progress in the science...' (ixx). As mentioned by Lyotard the grand narrative of western metaphysics is in the crisis because it has lost it's credibility. Moreover, he argues that knowledge is now the world's most significant commodity and that may well become sources of conflict between nations (Lyotard; 1979 cited in Sim's The Routledge Companion of Postmodernism, p.7).

Lyotard has reacted against the doctrinaire Marxism that is known as Post-Marxism. He insists that political control is possible over the common people due to the dissemination of knowledge. Knowledge is seen to be communicative through narrative, and he is very critical of what he calls grand narratives: theories that claim to be able to explain everything and to resist any attempt to change their form (Sim; 2011, P. 7). Marxism is one of the narratives which has its particular narrative of world history. It fells the truth that is beyond any kind of criticism or need for revision. Such an attitude, for Lyotard, is authoritarian, and he celebrates little narrative instead (Lyotard, P. 60). He considers that little narratives are the most inventive way of disseminating and creating knowledge and that they help to break down the monopoly of traditionally exercised grand narratives. Similarly, he claims that knowledge has lost emancipatory power in postmodernism. In the past, knowledge was limited to academics, was only the property of the academics, and language was not defined in terms of a game. Now, the situation has changed and language has changed into the TV game. The TV game has been sources of all knowledge, which has hybridism in its nature; 'serious and comic' and 'religious and secular'. The truth and center of language games have been shattered. Similarly, the truth of knowledge is found in the language game, which is different from one place to another place. Therefore, as the different natures of language, the reality of truth represented by the language is not the same. He informs us that postmodernism science is a search for paradoxes, instabilities, and the unknown rather than an attempt to construct yet another grand narrative (Sim; 2011, P.8). In this way, his main concern is to demolish the authority created by grandnarrative, for him, which is repressive of individual creativity. Therefore, he declares that 'we no longer have recourse to the grand narratives' (P. 60). He rejects the idea that is built on certain systems of thought or foundation. Postmodern philosophy has proved to be resolutely antifoundational in outlook.

Laaclau and Moufle also argue that "Marxism ought to be aligning itself with the various new social movements that have been springing up" (1985, P.33). They believe that Marxism needs to take account of the various theories that have been coming into prominence-theories deconstruction and postmodernism. Society has been plural; therefore, Marxism should attract new audiences in authoritarian cultural circumstances. Their main concern is that Marxism requires drastic revision or it should aspire towards pluralism instead of its supposed truth and universality of application.

Jean Baudriallard is another important strand of postmodern philosophy. He rejects the hidden structured notions of all phenomena, which are set up by the works of an analyst to identify and explain. He has claimed that the postmodern world is a world of Simulacra, where we can no longer differentiate between reality and simulation (Baudriallard, p. 70). A simulacrum represents nothing but themselves for him. There is no longer reality to which they refer. He argues that commodity and signs have combined to form a self-referential loop within a closed object system. Such a sign refers to something real and solid outside that system, this is an illusion. The thing which is generated by a sign system is a simulacrum, which acts as the external referent and justifies its functions. He has organized the history of the production of simulacra into three parts: classical era, industrial era, and postmodern order. In the classical era (from the Renaissance to the Industrial Revolution), simulation is taken place in the forms of counterfeiting. This is followed by the industrial era, in which techniques of mass reproduction allow an order of several reproducible objects. In contemporary postmodern order, new cybernetics and communications technologies have absorbed human subjectivity itself into a network of busily self-replicating digital systems. In the postmodern world, reality is transformed into hyper-reality which bears no relation to any reality whatsoever. The reality has disappeared entirely into the process of simulation.

\section{CONCLUSION}


Postmodern philosophy is to be said as an updated version of skepticism that has concerned with destabilizing other theories like Marxism, Structuralism, and so on and their created truth. It has deployed the authoritarian imperatives of our culture at both the theoretical and political levels. It emphasizes the subverting essential idea of the intellectual world by exposing the reality of it. The construction of grand narratives of Structuralism, Marxism, and philosophical history is dismantled, and all the intellectual authoritarianism have lost their credibility and legacy. Postmodern philosophy provides us the arguments and techniques to make the gesture of dissent, as well as the means to make value judgments in the absence of overall authorities. A boundary of long-running western intellectual thought, wisdom, culture, and so on stretched back to classical Greek philosophy are re-drawn and re-sketched with the eyes of the postmodern philosophy.

\section{REFERENCES}

[1] Abram, M.H. (2005). A Glossary of literary terms. $8^{\text {th }}$ Ed. United State of America: Thomson Wadsworth, P. 176.

[2] Baudrillard, J. (1983). Simulation, trans. Paul Foss, Paul Patton, and Philipp Beitchman. New York: Semiotest(s).

[3] Best, S. \& Kellner, D. (1991). Postmodern theory: critical interrogations. New York: Guilford Press.

[4] Cuddan, J.A. (1976). The penguin dictionary of literary terms and literary theory. 3rd Ed. Great Britain.

[5] Derrida, J. (1972). Margins of philosophy, Trans. Alan Bass (1982), Harvester: Brighton, P.3.

[6] Higgins, D. (1978). A Dialectic of centuries. New York: New York.

[7] Hundnut, J.(1949). Architecture and the spirit of man. Cambridge: Harvard University Press.

[8] Jacks, C.(1992). Cite in Sim's The Rutledge Companion of Postmodernism. The language of post-modern architecture, $6^{\text {th }}$ ed. London: Academy Editions.

[9] Laclau, E. \&Mouffe, C. (1985). Hegemony and socialist strategy: towards radical democratic politics. London: Verso.

[10] Lyotard, J. (1984). The Postmodern condition: a report of knowledge [1979] Trans. Geoff Bennington and Brian Massumi, Manchester: Manchester University Press, P.60.

[11] Murfin, R. \& Supria, M. (1998). The Bedford glossary of critical and literary terms. Boston: Bedford ST.

[12] Plotnitsky, A. (2001). Postmodernism and postmodernity: Literature, Criticism, Philosophy, and Culture, Anthropology, Introducing literary theories. Edinburg: Edinburg University Press.
[13] Ray, M. K. (2001). Studies of literary criticism. New Delhi: Atlantic Publisher and Distribution.

[14] Sim, S. (2011). The Routledge companion of postmodernism, $3^{\text {rd }}$ ed. New York: Routledge.

[15] Tyson, L. (2008). Critical theory today. New York/ London: Routledge.

[16] Toynbee, A. (1954). A Study of history, vol. IX. London: Oxford University Press.

[17] Woods, T. (2011). Beginning postmodernism. $2^{\text {nd }}$ ed. Manchester, UK: Manchester University Press. 